\title{
Early Viral Kinetics with Telbivudine, Tenofovir or Combination of Both in Immunotolerant Patients with Hepatitis B e Antigen-Positive Chronic Hepatitis B
}

Nancy W. Y. Leung • Eva Herrmann • George K. K. Lau • Henry L. Y. Chan • Tokutei M. K. So •

Stefan Zeuzem $\cdot$ Yu Dong $\cdot$ Aldo Trylesinski $\cdot$ Nikolai V. Naoumov

To view enhanced content go to www.infectiousdiseases-open.com

Received: July 15, 2014 / Published online: September 17, 2014

(c) The Author(s) 2014. This article is published with open access at Springerlink.com

\section{ABSTRACT}

Introduction: Viral kinetics has proved useful in understanding antiviral potency, determining antiviral profiles and optimizing treatment strategy.

Methods: This was a randomized, open-label study comparing the viral kinetics in 46 hepatitis $\mathrm{B}$ e antigen-positive patients during 12-week treatment with telbivudine monotherapy, tenofovir monotherapy or the

Trial registration: ClinicalTrials.gov \#NCT00804622.

Electronic supplementary material The online version of this article (doi:10.1007/s40121-014-0039-5) contains supplementary material, which is available to authorized users.

N. W. Y. Leung ( $₫)$

1501 Melbourne Plaza, 33 Queen's Road Central, Hong Kong S.A.R., China

e-mail: dr_nancyleung@yahoo.com.hk

\section{E. Herrmann}

Johann Wolfgang Goethe University

Frankfurt Department of Medicine,

Institute of Biostatistics and Mathematical

Modeling, Theodor-Stern-Kai 7,

Frankfurt am Main, Germany

G. K. K. Lau

The Institute of Translational Hepatology,

Beijing 302 Hospital, Beijing, China combination of telbivudine plus tenofovir. A standard biphasic mathematical model was used to compare hepatitis B virus (HBV) DNA decay parameters.

Results: Forty-six patients received telbivudine $(n=16)$, tenofovir $(n=14)$ or telbivudine plus tenofovir $(n=16)$. From baseline to Week 12, the mean (SD) reduction in HBV DNA levels was not significantly different between treatment groups: $\quad-3.9 \quad(0.9) \quad \log _{10} \quad$ copies $/ \mathrm{mL} \quad$ in telbivudine group, $-4.2(0.7) \log _{10}$ copies $/ \mathrm{mL}$ in tenofovir group, and -4.4 (1.0) $\log _{10}$ copies/ $\mathrm{mL}$ in combination group. No significant difference was observed among the three groups for viral clearance rate per day $(0.97$, 1.02 , and 0.88 , respectively) or for infected cell loss rate per day $(0.04,0.05$, and 0.05,

H. L. Y. Chan

Department of Medicine and Therapeutics, The Chinese University of Hong Kong,

Hong Kong S.A.R., China

T. M. K. So

Department of Medicine and Geriatrics, Princess

Margaret Hospital, Hong Kong S.A.R., China

S. Zeuzem

Klinikum der Johann Wolfgang Goethe-

Universitaet, Frankfurt am Main, Germany

Y. Dong $\cdot$ A. Trylesinski $\cdot$ N. V. Naoumov

Novartis Pharma AG, Basel, Switzerland 
respectively). Antiviral efficiency in blocking viral production was similar in the monotherapy groups (median; 99.7\% in telbivudine group and $99.4 \%$ in tenofovir group), but was slightly better and more homogeneous in the combination treatment group than in the monotherapy groups: mean (SD), 99.1\% (0.8\%) and $98.8 \%(1.6 \%)$, respectively (Wald-Wolfowitz test; $P=0.038)$. All treatments were well tolerated and no serious adverse event was reported during the study. Of the 46 patients in the safety population, 23 experienced adverse events. Most of the adverse events were not suspected to be related to the study drug by the investigators.

Conclusion: Monotherapy with telbivudine or tenofovir showed similar antiviral effectiveness in HBV DNA reduction and viral kinetics of HBV DNA decay. Efficiency in blocking viral production was slightly improved in the combination treatment group compared to the monotherapy groups.

Keywords: Chronic hepatitis B; Combination therapy; Hepatitis B virus; Infectious diseases; Telbivudine; Tenofovir; Viral kinetics

\section{INTRODUCTION}

Long-term suppression of serum hepatitis B virus (HBV) DNA is likely to reduce progression to cirrhosis and hepatic decompensation and to decrease the risk of hepatocellular carcinoma. Therefore, the primary goal of therapy for chronic hepatitis B (CHB) is suppression of viral replication [1-3].

No currently available single medication is able to achieve both potent HBV DNA suppression and high rates of hepatitis $\mathrm{B}$ e antigen (HBeAg) and hepatitis B surface antigen (HBsAg) clearance. Therefore, drug combination, which is a therapeutic strategy that has been shown to be successful to reduce viral resistance in human immunodeficiency virus (HIV) therapy, attracted some interest in CHB management. In initial trials evaluating the combination of pegylated interferon (PegIFN) and lamivudine, a slightly enhanced viral suppression and lower resistance rates were observed with the combination compared with either drug alone [4-6]. A clear advantage of the combination over each monotherapy treatment for long-term outcomes such as $\mathrm{HBeAg}$ or HBsAg seroconversion was not demonstrated.

In vitro, slightly synergistic effects to additive effects have been suggested for some combinations of nucleos(t)ides [7-9]. Telbivudine demonstrated additive to weakly synergistic anti-HBV activity in vitro when combined with tenofovir or entecavir; there was no evidence of cytotoxicity [10]. Previously, mathematical modeling of early HBV kinetics has been used to examine the efficacy of combination therapy with dual nucleos(t)ide analogs, namely famciclovir with lamivudine or adefovir with emtricitabine $[11,12]$.

Learning from these studies, the current investigation was designed to examine the effect of a combination of more potent antiviral agents, telbivudine and tenofovir disoproxil for chronic HBV infection. Unlike previous studies [13-16], immunotolerant patients were studied so as to avoid the interference of host immune system on the understanding of whether there is any true synergistic effect. These studies included lamivudine in the combination and demonstrated limited clinical benefit over monotherapy for virological endpoints [1719]. Analysis of resistance demonstrated that combination of lamivudine with another nucleoside or PegIFN was associated with lower resistance rates to lamivudine $[5,6,18$, 
19]. Nevertheless, current practice guidelines do not recommend combination of nucleos(t)ides as first-line treatment [1-3].

With the newest nucleosides/nucleotides such as telbivudine, tenofovir or entecavir, clinical trials comparing combination therapy with monotherapy are needed before combination therapy can be recommended as first-line therapy. The present study aimed to assess whether the combination therapy with telbivudine plus tenofovir has superior antiviral efficacy on the 1st and 2nd phase of HBV DNA decay compared to either drug as monotherapy. In these patients who are not considered as candidates for $\mathrm{CHB}$ therapy according to international guidelines, we assessed the early viral kinetics induced by telbivudine plus tenofovir combination therapy versus telbivudine or tenofovir monotherapy. Assessment of early viral kinetics provides critically important information in understanding antiviral potency, determining antiviral profiles and developing treatment strategy [13, 20, 21]. We used mathematical modeling of viral kinetics to compare HBV DNA decay parameters during initial 12-week treatment with telbivudine monotherapy, tenofovir monotherapy, or combination of telbivudine plus tenofovir.

\section{METHODS}

\section{Study Design and Patients}

This randomized, open-label, controlled, exploratory study assessed the reduction in HBV DNA level in patients with HBeAgpositive $\mathrm{CHB}$ treated with telbivudine monotherapy, tenofovir monotherapy, or combination of telbivudine plus tenofovir.

In total, 46 previously untreated patients with HBeAg-positive chronic HBV infection [with $\mathrm{HBV}$ DNA $\geq 10^{7} \quad \log _{10}$ copies/mL and alanine aminotransferase (ALT) $\leq 1 \times$ upper limit of normal (ULN)] were randomized (1:1:1) to receive a daily dose of telbivudine $600 \mathrm{mg}$ or tenofovir disoproxil fumarate $300 \mathrm{mg}$ or telbivudine plus tenofovir combination for 12 weeks (Table 1 ). Block randomization was used to maintain balance to each treatment group. After 12-week treatment, at the discretion of the investigator, patients would be continued for a further 36-week antiviral therapy or 12-week follow-up phase.

The study enrolled male and female patients of 18-40 years of age with documented HBeAg-positive CHB [defined as positive serum HBsAg for at least 6 months or HBsAg positive $>3$ months and with negative immunoglobulin $\mathrm{M}(\operatorname{IgM})$ anti-hepatitis B core antibody (HBc) and positive immunoglobulin $\mathrm{G}$ (IgG) anti-HBc], HBV DNA levels $\geq 7 \log _{10}$ copies/mL by $\operatorname{COBAS}^{\circledR}$ TaqMan $^{\circledR}$ HBV DNA assay (Roche, Basel, Switzerland) and serum ALT levels $\leq 1 \times$ ULN.

Key exclusion criteria were history of or clinical signs or symptoms of hepatic decompensation, prior treatment with interferon therapy within 6 months, $\alpha$-fetoprotein $>50 \mathrm{ng} / \mathrm{mL}$, evidence of hepatocellular carcinoma, coinfection with HIV-1 or hepatitis C or D virus, prior oral HBV therapy, significant renal, cardiovascular, pulmonary or neurological disease, calculated creatinine clearance $<70 \mathrm{~mL} / \mathrm{min}$ (CockroftGault equation), solid organ or bone marrow transplantation, treatment by any immunomodulatory treatment, hemoglobin level $<10 \mathrm{~g} / \mathrm{dL}$, absolute neutrophil count $<1,500 \mathrm{~mm}^{3}$, proximal tubulopathy, medical condition that required prolonged or frequent use of systemic acyclovir or famciclovir. Women who were pregnant, breastfeeding, or of child-bearing potential and not using 
acceptable methods of birth control were also ineligible.

All procedures followed were in accordance with the ethical standards of the responsible committee on human experimentation (institutional and national) and with the Helsinki Declaration of 1975, as revised in 2000 and 2008. This study was approved by local independent Ethics Committee. Informed consent was obtained from all patients for being included in the study.

\section{Efficacy Assessments}

Efficacy assessments included serum HBV DNA, HBeAg, antibodies to HBeAg, and ALT levels which were obtained at screening, baseline (Day 1 before dosing), Days 2, 4, 6, 8, 11, 15 (Week 2), 22 (Week 3), 29 (Week 4), 43 (Week 6), 57 (Week 8 ), and 85 (Week 12) and post-treatment followup visits at post-baseline Day 113 (Week 16), Day 141 (Week 20) and Day 169 (Week 24). The primary objective of the study was to characterize the reduction in HBV DNA level from baseline to Week 12 of telbivudine monotherapy, tenofovir monotherapy, and telbivudine plus tenofovir combination therapy. The secondary objective was to characterize early viral kinetics through estimation of various parameters including efficiency of blocking new virus production and half-lives of free virions and infected hepatocytes.

\section{HBV DNA Quantification}

Serum of patients was collected for HBV DNA measurement at baseline and at all scheduled visits. Serum HBV DNA determinations were conducted at a central laboratory using COBAS $\operatorname{TaqMan}^{\circledR}$ HBV DNA assay, which utilizes the real-time polymerase chain reaction.

\section{Viral Kinetics}

Viral kinetic parameters were estimated with a biphasic mathematical model of HBV DNA using compartments of free virus, infected cells and uninfected target cells [14, 22, 23]. The differential equation system of the underlying biphasic model of viral kinetics was as follows:

$$
\begin{aligned}
V^{\prime}(\mathrm{t}) & =(1-\varepsilon) p I(\mathrm{t})-c V(\mathrm{t}) \text { and } I^{\prime}(\mathrm{t}) \\
& =(1-\eta) \beta\left(T_{\mathrm{g}}-I(\mathrm{t})\right) V(\mathrm{t})-\delta I(\mathrm{t})
\end{aligned}
$$

where $V$ denotes serum viral load, I productively infected cells, $\varepsilon$ the efficiency factor of blocking virus production, $p$ the viral production rate, c the viral clearance rate, $\eta$ the efficiency factor of blocking de novo infection, $\beta$ the de novo infection rate, $T_{\mathrm{g}}$ comprises all infected and uninfected target cells, and $\delta$ the rate of infected cell loss [13, 14, 22].

Maximum-likelihood estimation methods for the viral kinetic parameters $c, \varepsilon$, and $\delta$ entailed the fitting of a nonlinear differential equation system via the least-squares approach from the serum HBV DNA data collected during the treatment period. In addition, $\eta=0.5$ was used as in previous analyses and the viral kinetic parameters for $p$ and $\beta$ can be derived from the others when assuming a steady state before treatment starts. MATLAB (MathWorks Inc., Natick, MA, USA) routines were used to calculate these estimates.

\section{Safety Assessment}

Vital signs, physical examination and laboratory parameters were collected at screening, baseline and at all scheduled visits. All adverse events and serious adverse events were reported with their severity and relationship to the study drug. 


\section{Statistical Analysis}

All efficacy assessments were performed on the intent-to-treat population, which consisted of all patients who had been randomized and had received at least one dose of study drug. Kruskal-Wallis test and nonparametric WaldWolfowitz test were used to compare the data and to assess data variability, respectively. The safety population consisted of patients that had been randomized and had taken at least one dose of the study drug. All statistical tests were bilateral with a 0.05 alpha level of significance.

\section{RESULTS}

\section{Patient Disposition}

Forty-seven patients met the inclusion/ exclusion criteria (Table 1). One patient withdrew consent and 46 patients were randomized and included in the intent-to-treat analysis. All 46 randomized patients completed the 12-week treatment except one patient in the combination group who discontinued at Week 1 due to an adverse event (nausea and dyspepsia). Treatment groups were comparable at baseline except the percentage of men, which was slightly lower in the telbivudine plus tenofovir combination group (38\%) compared to the telbivudine group (56\%) or to the tenofovir group (64\%). HBV DNA levels at baseline were comparable between the three treatment groups.

Mean (SD) exposure to study drugs was comparable between treatment groups: 84.6 (1.8) days in telbivudine group, 84.8 (1.7) days in tenofovir group, and 80.1 (19.7) days in telbivudine plus tenofovir group. The compliance of drug intake in the two monotherapy arms was similar and slightly less in the combination arm.

\section{HBV DNA Decline}

The mean HBV DNA reduction in the three treatment arms was almost identical (Fig. 1). As soon as Day 2, the mean decrease of HBV DNA level was $-0.53 \log _{10}$ copies $/ \mathrm{mL}$ in telbivudine group, $-0.58 \log _{10}$ copies $/ \mathrm{mL}$ in tenofovir group and $-0.54 \log _{10}$ copies/mL in combination group.

Since Week 3, the mean (SD) HBV DNA reduction was numerically higher in the combination group compared to the monotherapy groups: telbivudine plus

Table 1 Patient demographics and baseline characteristics

\begin{tabular}{lccc}
\hline Characteristic & $\begin{array}{l}\text { Telbivudine } \\
(\boldsymbol{N}=\mathbf{1 6})\end{array}$ & $\begin{array}{l}\text { Tenofovir } \\
(\boldsymbol{N}=\mathbf{1 4})\end{array}$ & $\begin{array}{l}\text { Telbivudine plus } \\
\text { tenofovir }(\boldsymbol{N}=\mathbf{1 6})\end{array}$ \\
\hline Age, mean (SD), years & $28.0(7.6)$ & $27.3(4.9)$ & $28.9(5.6)$ \\
Gender, $n$ (\%) & $9(56)$ & $9(64)$ & $6(38)$ \\
Male & $7(44)$ & $5(36)$ & $10(63)$ \\
Female & $16(100)$ & $14(100)$ & $16(100)$ \\
Asian (Chinese) patients, $n(\%)$ & $16(100)$ & $14(100)$ & $16(100)$ \\
HBeAg-positive, $n$ (\%) & $8.98(0.59)$ & $8.78(0.87)$ & $8.89(0.60)$ \\
Baseline HBV DNA, mean (SD), $\log _{10}$ copies/mL & $31.6(12.8)$ & $33.9(18.6)$ & $33.3(21.2)$ \\
Baseline ALT level, mean (SD), IU/L & &
\end{tabular}

ALT Alanine aminotransferase, $H B e A g$ Hepatitis B e antigen, $H B V$ Hepatitis B virus, SD Standard deviation 


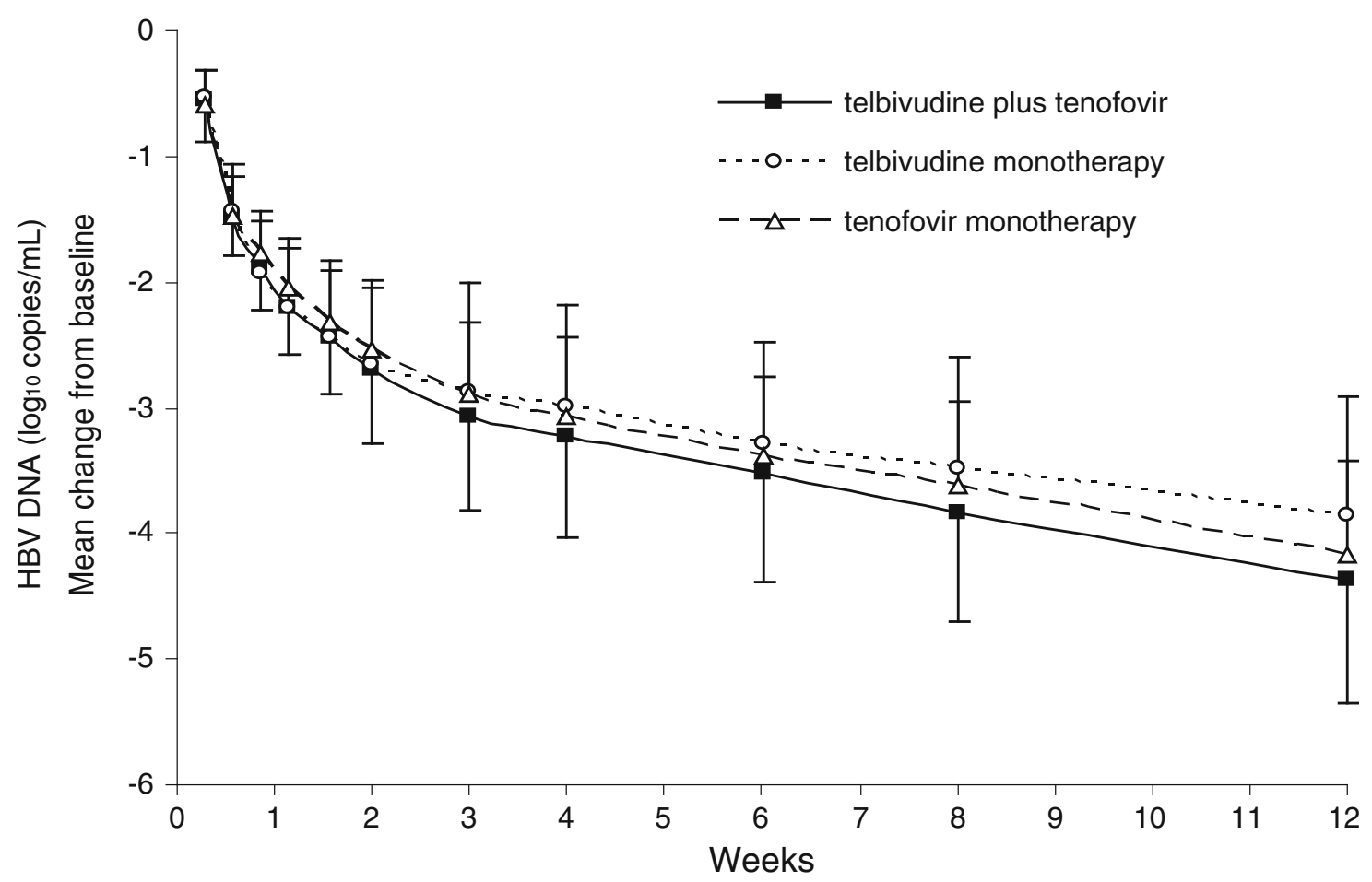

Fig. 1 Mean HBV DNA decline over time by treatment groups (intent-to-treat population). Error bars are standard deviations. $H B V$ Hepatitis $\mathrm{B}$ virus

tenofovir, $\quad-3.1 \quad(0.7) \quad \log _{10} \quad$ copies $/ \mathrm{mL} ;$ as compared to $-2.9(0.9) \log _{10}$ copies/mL in telbivudine monotherapy group and $-2.9(0.6)$ $\log _{10}$ copies/mL in tenofovir monotherapy group. At Week 12, the greater HBV DNA reduction in the combination group persisted with mean (SD) decrease of -4.4 (1.0) $\log _{10}$ copies/mL in the combination group compared to $-3.9(0.9) \log _{10}$ copies/mL in telbivudine group and $-4.2(0.7) \quad \log _{10}$ copies $/ \mathrm{mL}$ in tenofovir group (Fig. 1). Combination treatment provided slightly more decrease of HBV DNA copies from baseline to Week 12 than telbivudine or tenofovir. However, the differences between the three groups did not achieve statistical significance.

One female patient of 40 years of age in the combination group achieved undetectable serum HBV DNA $(<169$ copies/mL $)$ and became HBeAg negative at Week 12. This patient had a medical history of compensated $\mathrm{CHB}$ and at baseline HBV DNA level was $28,750,800$ copies/mL and ALT level was $61 \mathrm{IU} / \mathrm{L}$.

\section{Viral Kinetics}

The data supported the biphasic model for viral kinetics and no patient showed deviation from the biphasic pattern. There were no significant differences between the three groups in terms of viral clearance rate per day (parameter $c$ : 0.97 for telbivudine, 1.02 for tenofovir, and 0.88 for telbivudine plus tenofovir) or infected cell loss rate per day (parameter $\delta: 0.04,0.05$, and 0.05, respectively; Table 2).

Efficiency in blocking viral production ( $\varepsilon$ parameter) was not significantly different between the two monotherapy groups (median at $99.7 \%$ in telbivudine group and $99.4 \%$ in 
Table 2 Viral kinetics parameters

\begin{tabular}{|c|c|c|c|}
\hline Parameter & $\begin{array}{l}\text { Telbivudine } \\
(N=16)\end{array}$ & $\begin{array}{l}\text { Tenofovir } \\
(N=14)\end{array}$ & $\begin{array}{l}\text { Telbivudine plus } \\
\text { tenofovir }(N=16)\end{array}$ \\
\hline \multicolumn{4}{|c|}{ Viral clearance rate/day, $c$} \\
\hline Median & 0.97 & 1.02 & 0.88 \\
\hline Range & $0.52-1.25$ & $0.66-2.87$ & $0.51-3.75$ \\
\hline \multicolumn{4}{|c|}{ Infected cell loss rate/day, $\delta$} \\
\hline Median & 0.04 & 0.05 & 0.05 \\
\hline Range & $0.01-0.07$ & $0.03-0.09$ & $0.01-0.10$ \\
\hline \multicolumn{4}{|c|}{ Efficiency factor of blocking virus production, $\varepsilon(\%)$} \\
\hline Median & 99.7 & 99.4 & 99.5 \\
\hline Range & $94.7-99.9$ & $94.6-99.8$ & $97.6-99.95$ \\
\hline \multicolumn{4}{|c|}{ Half-life of free virus $(\mathrm{h})$} \\
\hline Median & 17.1 & 16.5 & 18.9 \\
\hline Range & $13.3-32.2$ & $5.8-25.2$ & $4.4-32.8$ \\
\hline \multicolumn{4}{|c|}{ Half-life of infected cells (days) } \\
\hline Median & 16.2 & 12.9 & 14.1 \\
\hline Range & $10.2-69.3$ & $7.8-22.5$ & $7.2-69.3$ \\
\hline
\end{tabular}

tenofovir group; Kruskal-Wallis test; Table 2). This viral kinetics parameter was more homogeneous in the combination treatment group than in the monotherapy groups: mean (SD), $99.1 \% \quad(0.8 \%)$ and $98.8 \% \quad(1.6 \%)$, respectively (Wald-Wolfowitz test; $P=0.038$ ).

Figure 2 shows that first-phase log decay of virus was overall comparable in the three groups. Data in the telbivudine group showed a slightly higher median value compared to tenofovir monotherapy or combination treatment group. Furthermore, the minimum and maximum values of the combination treatment group were higher than the other treatment groups.

\section{Safety}

All treatments were well tolerated and no serious adverse event was reported during the study. The adverse events reported were

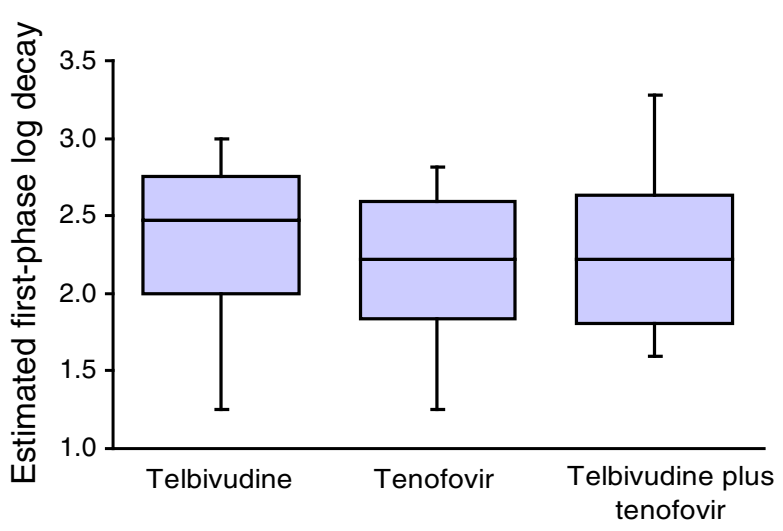

Fig. 2 Box-plots for the first-phase decay of viral kinetics by treatment groups (intent-to-treat population). The boxes show the ranges of estimated first-phase log decay between the $25 \%$ and $75 \%$ quartiles; the median is shown by the line and the vertical lines represent the range (the smallest and largest values in each group)

expected for this study population and class of drug. Of the 46 patients in the safety population, 23 experienced adverse events (16 events in telbivudine, 14 in tenofovir, and 16 in 
combination group). The commonly reported adverse events were nausea (12.5\%) and influenza (12.5\%) in combination group; influenza (31.3\%) and influenza-like illness (25\%) in telbivudine group; influenza $(21.4 \%)$, influenza-like illness (14.3\%), and upper abdominal pain $(14.3 \%)$ in tenofovir group, respectively.

Most of the adverse events were considered as not suspected to be related to study drug by investigators. Adverse events reported to be related to study drug were dizziness $(n=1$; drug combination), dyspepsia $(n=1 ;$ drug combination), nausea $\quad(n=2 ; \quad$ drug combination), upper abdominal pain $(n=1$; tenofovir), and somnolence ( $n=1$; tenofovir).

Two muscle-related adverse events were reported. None were considered to be drug related. One was reported in the tenofovir group (mild "lower limb muscle cramp") and the other was reported in the tenofovir and telbivudine combination group (mild "neck stiffness").

No renal-related adverse event was reported during the study. There was no significant change in the mean glomerular filtration rate [modification of diet in renal disease (MDRD) formula] in all 3 groups.

No patient at baseline had grade $3-4$ creatine kinase abnormality or during the course of the study. Three patients (one in each of the three treatment groups) experienced ALT elevation $\geq 2 \times$ baseline (and $\geq 2 \times$ ULN) during the study period. ALT levels elevated and reached peak approximately at Week 6 or Week 8 and decreased along with time without drug discontinuation. All three patients have completed 12-week study treatment period.

\section{DISCUSSION}

This study provides the first head-to-head comparison of the viral kinetics profiles of telbivudine $600 \mathrm{mg} /$ day and tenofovir $300 \mathrm{mg} /$ day for treatment-naïve patients with HBeAgpositive $\mathrm{CHB}$. There was a comparable early reduction in mean HBV DNA levels over time in both monotherapy groups.

Differences in treatment responses have been related to different factors such as HBV genotype, baseline ALT level, HBeAg status, previous treatment history for $\mathrm{CHB}$ or drug pharmacokinetics [14, 24, 25]. In addition, it has been shown that distinct patterns of viral kinetics are associated to different antiviral treatments [25]. Thus, we used a biphasic model that allowed comparisons with other recent trials aimed to characterize the early viral kinetics during treatment of $\mathrm{CHB}$. In this biphasic model, the viral kinetics depends of three parameters during the first month of treatment. The effectiveness $(\varepsilon)$ of blocking virion production is estimated by the first phase of DNA decline; the half-life of the free virions $(c)$ is estimated by the first-phase slope and the half-life of infected cells $(\delta)$ is estimated from second-phase slope. The modeling of $\mathrm{CHB}$ infection under treatment is expected to predict long-term prediction of antiviral response with the hope that future researches will allow to define individualized treatments according to early viral kinetics parameters [14, 26-28].

The authors' analysis of the early viral kinetics during the first weeks after treatment initiation is consistent with previous data [1316]. During the 12 weeks of treatment, a biphasic decline of HBV DNA was observed: the first phase consisted in a rapid decline in HBV DNA levels for approximately 2 weeks, followed by a second phase with a less rapid steady decrease in HBV DNA levels. The viral kinetic parameters were comparable between the two monotherapy groups with respect to viral clearance per day, rate of infected cell loss 
per day, and efficiency of blocking viral replication.

This viral kinetics study demonstrates that telbivudine and tenofovir have the same potency. Similar results were reported in a previous published study by Suh et al. [13] comparing telbivudine versus entecavir which showed similar potency between entecavir and telbivudine. The 12-week study by Suh et al. [13] in HBeAg-positive patients (with ALT $\geq 1.3 \times$ ULN) has shown equal potency in an analysis comparing the viral kinetics parameters with telbivudine (HBV DNA reduction, $-6.6 \pm 1.6 \log _{10}$ copies $\left./ \mathrm{mL}\right)$ versus entecavir $\quad\left(-6.5 \pm 1.5 \quad \log _{10} \quad\right.$ copies $\left./ \mathrm{mL}\right)$ treatment. There were no significant differences between groups for mean values of viral clearance by day, loss of infected cells per day or efficiency of blocking viral production. Consistent with this previous study, we report that the HBV DNA decrease was evident as soon as Day 2 after treatment initiation and was sustained during the 12-week treatment. The mean estimate of efficiency in blocking viral production $(99.7 \%)$ was also consistent with the mean estimate of efficiency reported by Suh et al. [13] (99.1\%).

Another study comparing telbivudine and entecavir for early response has been reported by Shi et al. [29] in HBeAg-positive patients. This study confirmed earlier results showing no difference in the mean reduction in HBV DNA levels between the treatment groups $\quad\left(\begin{array}{llll}-5.27 & \log _{10} & \text { copies } / \mathrm{mL} & \text { for }\end{array}\right.$ telbivudine and $-5.36 \log _{10}$ copies $/ \mathrm{mL}$ for entecavir) [29]. Of interest, Shi et al. [29] have studied the relationship between the early and profound suppression of HBV DNA and the HBeAg seroconversion rate. These authors observed that, despite that $\mathrm{HBeAg}$ seroconversion is usually a rare event during the first 3 months of treatment with nucleos(t)ide treatment, higher rates of HBeAg seroconversion were achieved in telbivudine-treated patients compared to entecavir-treated patients at Week 12 (20\% vs. $5 \%$, respectively; $P=0.043$ ) and Week 24 (27.5\% vs. $17.5 \% ; P>0.05)$ [29]. To explain this finding, an additional mechanism of action for telbivudine in the suppression of HBV replication has been suggested. Preliminary results suggest that telbivudine could exert antiviral effect not only directly by inhibiting viral replication, but also by stimulating the host immune system [30-32]. Further studies are necessary to confirm that this effect on the immune system contributes to the high HBeAg seroconversion rates reported in long-term studies in telbivudine-treated HBeAg-positive patients [33-35].

In the current study, both monotherapies had similar reduction [-4.374 (telbivudine + tenofovir) vs. -3.852 (telbivudine) vs. -4.175 (tenofovir) $\log _{10}$ copies $\left./ \mathrm{mL}\right]$, however, these differences did not achieve statistical significance (for tenofovir vs. telbivudine + tenofovir). In the telbivudine plus tenofovir combination group, there was an additional benefit in HBV DNA reduction at Week 12. This was supported by the more homogeneous efficiency of blocking viral replication in this combination group. Although these differences did not achieve statistical significance, the limitation of the study to 12 weeks did not allow evidencing an improvement of this difference after Week 12. Tenofovir use may be limited by nephrotoxicity especially in patient with high renal risk. Prospective and retrospective data on telbivudine suggest that telbivudine may have potential renal protective action as estimated by MDRD, mainly in patient 
with high renal risk (older, nephrotoxic agents, transplant) [36]. All these evidences support the use of this combination as potential optimal combination regimens.

Furthermore, in the GLOBE trial (ClinicalTrials.gov \#NCT00057265), the proportions of telbivudine-treated patients with undetectable HBV DNA increased markedly between treatment weeks 12 and 24: from $19 \%$ to $45 \%$ in $\mathrm{HBeAg}$-positive patients [37]. Moreover, in the GLOBE trial, all outcomes at 2 years of $\mathrm{HBeAg}$-positive patients were improved for patients with undetectable HBV DNA levels at treatment week 12 or week 24: the difference was particularly marked after comparison with patients with serum HBV DNA $>4 \log _{10}$ copies/mL [38].

The safety and tolerability of the treatment in this study were favorable. No patient experienced renal function impairment; there were no significant changes in the mean glomerular filtration rate compared with baseline in the three groups.

\section{CONCLUSION}

This viral kinetics study demonstrates that viral kinetics parameters were comparable between the telbivudine and tenofovir groups with respect to viral clearance per day, rate of infected cell loss per day and efficiency of blocking viral replication. First-phase decay of virus in the telbivudine group showed a slightly higher median value. The telbivudine and tenofovir combination group showed additional benefit in HBV DNA reduction at Week 12. This was supported by the more homogeneous efficiency of blocking viral replication in telbivudine and tenofovir combination group.

\section{ACKNOWLEDGMENTS}

This study and the article processing charges were funded by Novartis Pharma AG, Basel, Switzerland. The study was designed by GKKL, SZ, and NVN; NWYL was the principal investigator; NWYL, GKKL, HLYC, TMKS, YD, and AT did data analyses; EH performed the modeling, all authors were involved in the manuscript writing and approval. All named authors meet the ICMJE criteria for authorship for this manuscript, take responsibility for the integrity of the work and have given final approval to the version to be published. All authors had full access to all of the data in this study and take complete responsibility for the integrity of the data and accuracy of the data analysis.

Conflict of interest. NWYL, EH, GKKL, and TMKS declare no conflict of interest. HLYC is an advisor speaker for BMS, Gilead, Novartis, Roche and MSD, speaker for Abbvie, Echosens and GSK, has received unrestricted grant from Roche. SZ is a consultant and member of speaker's bureau for BMS, Gilead, and Novartis. YD is an employee of Novartis Pharma AG, Basel, Switzerland. AT is an employee of Novartis Pharma AG, Basel, Switzerland. NVN is an employee of Novartis Pharma AG, Basel, Switzerland.

Compliance with ethics guidelines. All procedures followed were in accordance with the ethical standards of the responsible committee on human experimentation (institutional and national) and with the Helsinki Declaration of 1975, as revised in 2000 and 2008. This study was approved by local independent Ethics Committee. Informed consent was obtained from all patients for being included in the study. 
Open Access. This article is distributed under the terms of the Creative Commons Attribution Noncommercial License which permits any noncommercial use, distribution, and reproduction in any medium, provided the original author(s) and the source are credited.

\section{REFERENCES}

1. European Association for the Study of the Liver. EASL clinical practice guidelines: management of chronic hepatitis B. J Hepatol. 2009;50:227-42.

2. Liaw YF, Leung $\mathrm{N}$, Kao JH, et al. Asian-Pacific consensus statement on the management of chronic hepatitis B: a 2008 update. Hepatol Int. 2008;2:263-83.

3. Lok AS, Mcmahon BJ. Chronic hepatitis B: update 2009. Hepatology. 2009;50:661-2.

4. Janssen HL, Van Zonneveld M, Senturk H, et al. Pegylated interferon alfa- $2 b$ alone or in combination with lamivudine for $\mathrm{HBeAg}$-positive chronic hepatitis B: a randomised trial. Lancet. 2005;365:123-9.

5. Lau GK, Piratvisuth T, Luo KX, et al. Peginterferon Alfa-2a, lamivudine, and the combination for HBeAg-positive chronic hepatitis B. N Engl J Med. 2005;352:2682-95.

6. Marcellin P, Lau GK, Bonino F, et al. Peginterferon alfa-2a alone, lamivudine alone, and the two in combination in patients with HBeAg-negative chronic hepatitis B. N Engl J Med. 2004;351:1206-17.

7. Delaney WET, Yang H, Miller MD, Gibbs CS, Xiong S. Combinations of adefovir with nucleoside analogs produce additive antiviral effects against hepatitis B virus in vitro. Antimicrob Agents Chemother. 2004;48:3702-10.

8. Seigneres B, Martin P, Werle B, et al. Effects of pyrimidine and purine analog combinations in the duck hepatitis B virus infection model. Antimicrob Agents Chemother. 2003;47:1842-52.

9. Zhu Y, Curtis M, Qi X, Miller MD, Borroto-Esoda K. Anti-hepatitis $\mathrm{B}$ virus activity in vitro of combinations of tenofovir with nucleoside/ nucleotide analogues. Antivir Chem Chemother. 2009;19:165-76.
10. Patty A, Li B, Serra I, Standring DN, Seifer M. In vitro anti-HBV activity of telbivudine/tenofovir and telbivudine/entecavir combinations. Hepatology. 2007;46:A663.

11. Lau GK, Cooksley H, Ribeiro RM, et al. Impact of early viral kinetics on $\mathrm{T}$-cell reactivity during antiviral therapy in chronic hepatitis B. Antivir Ther. 2007; 12:705-18.

12. Lau GK, Tsiang M, Hou J, et al. Combination therapy with lamivudine and famciclovir for chronic hepatitis B-infected Chinese patients: a viral dynamics study. Hepatology. 2000;32:394-9.

13. Suh DJ, Um SH, Herrmann E, et al. Early viral kinetics of telbivudine and entecavir: results of a 12-week randomized exploratory study with patients with HBeAg-positive chronic hepatitis B. Antimicrob Agents Chemother. 2010;54:1242-7.

14. Sypsa V, Hatzakis A. Modelling of viral dynamics in hepatitis B and hepatitis C clinical trials. Stat Med. 2008;27:6505-21.

15. Lai CL, Lim SG, Brown NA, et al. A dose-finding study of once-daily oral telbivudine in HBeAgpositive patients with chronic hepatitis B virus infection. Hepatology. 2004;40:719-26.

16. Leung N, Peng CY, Hann HW, et al. Early hepatitis $B$ virus DNA reduction in hepatitis $B$ e antigenpositive patients with chronic hepatitis B: a randomized international study of entecavir versus adefovir. Hepatology. 2009;49:72-9.

17. Hui CK, Zhang HY, Bowden S, et al. 96 weeks combination of adefovir dipivoxil plus emtricitabine vs. adefovir dipivoxil monotherapy in the treatment of chronic hepatitis B. J Hepatol. 2008;48:714-20.

18. Lai CL, Leung N, Teo EK, et al. A 1-year trial of telbivudine, lamivudine, and the combination in patients with hepatitis B e antigen-positive chronic hepatitis B. Gastroenterology. 2005;129:528-36.

19. Sung JJ, Lai JY, Zeuzem S, et al. Lamivudine compared with lamivudine and adefovir dipivoxil for the treatment of HBeAg-positive chronic hepatitis B. J Hepatol. 2008;48:728-35.

20. Lai CL, Gane E, Liaw YF, et al. Telbivudine versus lamivudine in patients with chronic hepatitis B. N Engl J Med. 2007;357:2576-88.

21. Marcellin P, Heathcote EJ, Buti M, et al. Tenofovir disoproxil fumarate versus adefovir dipivoxil for chronic hepatitis B. $N$ Engl J Med. 2008;359:2442-55. 
22. Mihm U, Gartner BC, Faust D, et al. Viral kinetics in patients with lamivudine-resistant hepatitis B during adefovir-lamivudine combination therapy. J Hepatol. 2005;43:217-24.

23. Herrmann E, Lee JH, Marinos G, Modi M, Zeuzem S. Effect of ribavirin on hepatitis $\mathrm{C}$ viral kinetics in patients treated with pegylated interferon. Hepatology. 2003;37:1351-8.

24. Wolters LM, Hansen BE, Niesters HG, Zeuzem S, Schalm SW, De Man RA. Viral dynamics in chronic hepatitis B patients during lamivudine therapy. Liver. 2002;22:121-6.

25. Neumann AU. Hepatitis B viral kinetics: a dynamic puzzle still to be resolved. Hepatology. 2005;42:249-54.

26. Brunetto MR, Colombatto P, Bonino F. Biomathematical models of viral dynamics to tailor antiviral therapy in chronic viral hepatitis. World J Gastroenterol. 2009;15:531-7.

27. Dahari H, Cotler SJ, Layden TJ, Perelson AS. Hepatitis B virus clearance rate estimates. Hepatology. 2009;49:1779-80.

28. Locarnini SA. Clinical relevance of viral dynamics and genotypes in hepatitis B virus. J Gastroenterol Hepatol. 2002;17(Suppl 3):S322-8.

29. Shi KQ, Zhang DZ, Guo SH, et al. Short-term results of telbivudine versus entecavir treatments in HBeAg-positive chronic hepatitis $B$ patients in China. Zhonghua Gan Zang Bing Za Zhi. 2008; 16:641-5.

30. Wu ZG, Yan WM, Guo W, et al. Telbivudine preserves TH1 cytokine response and down regulates PD-L1 in MHV-3-induced viral hepatitis model. Hepatology. 2009;50:535A.
31. Chen Y, Li XF, Ye B, et al. Effect of telbivudine therapy on the cellular immune response in chronic hepatitis B. Antivir Res. 2011;91:23-31.

32. Evans A, Riva A, Cooksley $\mathrm{H}$, et al. Programmed death 1 expression during antiviral treatment of chronic hepatitis B: impact of hepatitis B e-antigen seroconversion. Hepatology. 2008;48:759-69.

33. Gane EJ, Wang Y, Liaw YF, et al. Efficacy and safety of prolonged 3-year telbivudine treatment in patients with chronic hepatitis B. Liver Int. 2011;31:676-84.

34. Hou J, Xu D, Shi G, et al. Five-year telbivudine treatment with effective viral suppression results in resolution of liver inflammation and fibrosis regression in patients with chronic hepatitis B. J Hepatol. 2011;54:S287.

35. Wang Y, Thongsawat S, Gane EJ, et al. Efficacy and safety of continuous 4-year telbivudine treatment in patients with chronic hepatitis B. J Viral Hepat. 2013;20:e37-46.

36. Gane EJ, Deray G, Liaw YF, et al. Telbivudine improves renal function in patients with chronic hepatitis B. Gastroenterology. 2014;146:138-46.

37. Liaw YF, Gane E, Leung N, et al. 2-year GLOBE trial results: telbivudine is superior to lamivudine in patients with chronic hepatitis B. Gastroenterology. 2009;136:486-95.

38. Zeuzem S, Gane E, Liaw YF, et al. Baseline characteristics and early on-treatment response predict the outcomes of 2 years of telbivudine treatment of chronic hepatitis B. J Hepatol. 2009;51:11-20. 